\title{
KEBERFUNGSIAN KELUARGA BURUH WANITA PLASMA INDUSTRI BULU MATA PALSU DI DESA GRANTUNG KECAMATAN KARANGMONCOL KABUPATEN PURBALINGGA
}

\author{
Wahyu Syabani Anistiarini \\ Politeknik Kesejahteraan Sosial Bandung, wahyusyabani17@gmail.com \\ Theresia Martina Marwanti \\ Politeknik Kesejahteraan Sosial Bandung, martina.wanti@gmail.com \\ Wawan Heryana \\ Politeknik Kesejahteraan Sosial Bandung, wheryana@yahoo.com
}

\begin{abstract}
The false eyelash industry in Purbalingga has penetrated international market and become an import commodity, so entrepreneurs innovate to expand their business with industrial plasma systems. Workers from the plasma of the industry almost entirely are women who have been family and are on the line of poverty, this is encouraging to the emergence of the problem of family functioning one of them in the village Grantung. This research aims to obtain a empirical overview of 1) the characteristics of respondents; 2) connection aspects; 3) asset aspect; and 4) environmental aspects. This research uses a descriptive method with a quantitative approach. Determination of the sample number of respondents using the survey technique is the entire population of 25 women laborers plasma false eyelash industry. The data collection techniques used are 1) questionnaires and 2) documentation studies. The results showed that the functioning aspect of the respondent family was in a less good category - quite well, with the lowest aspect being the connection aspect having a score of 531. While the other aspect, the asset aspect has a score of 733, the relationship aspect has a score of 715, and the environmental aspect has a score of 562. However, the low functioning of the respondent's family is due to the low level of education and skill and the absence of the Assembly that advocates for the welfare of respondents. Therefore, to address the problem, researchers proposed the program "Perhimpunan Srikandi Perwira dalam Peningkatan Keberfungsian Keluarga Buruh Wanita Plasma Industri Bulu Mata Palsu di Desa Grantung Kecamatan Karangmoncol Kabupaten Purbalingga”, which aims to improve the functioning of the family and welfare workers of women Plasma industry false eyelashes.
\end{abstract}

Keywords:

Functional Family; Labour Women Plasma. Industry False Eyelashes; Poverty 


\begin{abstract}
Abstrak
Industri bulu mata palsu di Purbalingga telah menembus pasar internasional dan menjadi komoditas impor, sehingga pengusaha berinovasi untuk mengembangkan bisnisnya dengan sistem plasma industri. Pekerja dari plasma industri hampir seluruhnya adalah perempuan yang telah berkeluarga dan berada di garis kemiskinan, hal ini mendorong munculnya masalah keberfungsian keluarga salah satunya di desa Grantung. Penelitian ini bertujuan untuk mendapatkan data empiris 1) karakteristik responden; 2) aspek koneksi; 3) aspek aset; dan 4) aspek lingkungan. Penelitian ini menggunakan metode deskriptif dengan pendekatan kuantitatif. Penentuan jumlah sampel responden yang menggunakan teknik survei adalah seluruh populasi 25 perempuan buruh plasma industri bulu mata palsu. Teknik pengumpulan data yang digunakan adalah 1) kuesioner dan 2) studi dokumentasi. Hasil penelitian menunjukkan bahwa aspek fungsi keluarga responden berada dalam kategori yang kurang baik - cukup baik, dengan aspek terendah adalah aspek koneksi memiliki skor 531. Sementara aspek lainnya, aspek aset memiliki skor 733, aspek hubungan memiliki skor 715, dan aspek lingkungan memiliki skor 562. Namun, rendahnya keberfungsian keluarga responden disebabkan oleh rendahnya tingkat pendidikan dan keterampilan serta tidak adanya wadah perkumpulan yang memperjuangkan kesejahteraan responden. Oleh karena itu, untuk mengatasi permasalahan tersebut, peneliti mengusulkan program "Perhimpunan Srikandi Perwira dalam Peningkatan Keberfungsian Keluarga Buruh Wanita Plasma Industri Bulu Mata Palsu di Desa Grantung Kecamatan Karangmoncol Kabupaten Purbalingga", yang bertujuan untuk meningkatkan keberfungsian keluarga dan kesejahteraan pekerja perempuan Plasma industri bulu mata palsu.
\end{abstract}

\title{
Kata Kunci: \\ Keberfungsian Keluarga; Buruh Wanita Plasma, Industri Bulu Mata Palsu; Kemiskinan
}

\section{PENDAHULUAN}

Kemiskinan di Kabupaten Purbalingga menempati peringkat ke-5 sebagai kabupaten termiskin se-Propinsi Jawa Tengah sampai pada tahun 2019. Berdasarkan data Badan Pusat Statistik Kabupaten Purbalingga tahun 2019, sejak tahun 2016 - 2018 indeks kedalaman dan keparahan kemiskinan di Kabupaten Purbalingga mengalami fluktuasi yang disebabkan karena kondisi pengangguran terbuka berada di angka 6,06\% diatas angka propinsi dan nasional. Hal ini disebabkan karena kelesuan perekonomian global yang berdampak pada lesunya industri rambut dan bulu mata palsu, sehingga beberapa pabrik juga melakukan pengurangan karyawan untuk memangkas beban perusahaan.
Industri bulu mata palsu di Kabupaten Purbalingga berdiri sejak tahun 1970-an dan telah menembus pasar internasional. Kualitasnya di akui dunia dan membuatnya menjadi industri terbesar nomor 2 setelah Guangzhuo Cina. Sayangnya saat ini pasar ekspor bulu mata palsu di negara-negara tujuan sedang mengalami kelesuan karena ketatnya persaingan dengan Guangzhuo Cina. Apabila hal ini terus berlanjut maka ada kemungkinan perusahaan-perusahaan bulu mata palsu tersebut gulung tikang dan para investor akan berpindah menginvestasikan modalnya ke negara lain. Padahal industri bulu mata palsu ini berdasarkan Laporan Wartawan Tribun Jawa Tengah tahun 2019, Khoirul Muzzaki, perusahaan bulu mata palsu mampu menyerap 
sekitar 45 ribu tenaga kerja. Oleh karenanya, pengusaha bulu mata palsu perlu di dorong untuk terus mengembangkan inovasi bisnis agar kualitas dan kuantitas barang tetap stabil sesuai dengan permintaan pasar serta memiliki harga yang bersaing dengan produk dari negara lain.

Salah satu strategi yang ditempuh oleh setiap perusahaan bulu mata palsu saat ini adalah dengan melakukan perluasan industri bulu mata palsu dengan melibatkan para pekerja rumahan yang tersebar di berbagai pelosok desa di Kabupaten Purbalingga. Cabang-cabang industri dari perusahaan pusat ini juga diatur dalam Peraturan Pemerintah Nomor 44 tahun 1997 tentang kemitraan, yang dinamakan pola inti - plasma. Pola inti plasma atau biasa disebut oleh pengusaha bulu mata palsu sebagai plasma industri, merupakan salah satu jenis pola kemitraan yang merupakan penyokong produksi terhadap industri yang ada di pusat kota. Plasma industri ini melibatkan keluarga dari berbagai kalangan untuk memproduksi bulu mata palsu setengah jadi dengan bahan produksi dan alat yang disediakan oleh perusahaan pusat. Berpegang pada PP No.44/1997 tersebut, maka perusahaan pusat sangat berharap apabila kemitraan intiplasma ini dapat meningkatkan produktivitas dan mampu memenuhi kebutuhan pasar kembali.

Grantung merupakan salah satu dari sebelas desa di Kecamatan Karangmoncol Kabupaten Purbalingga yang dijadikan sebagai kawasan plasma industri bulu mata palsu. Berdasarkan Profil Desa Grantung tahun 2019, mayoritas buruh plasma industri yang berada di Desa Grantung adalah wanita karena untuk menganyam bulu mata palsu, dibutuhkan keterampilan dan keuletan yang tinggi. Aktivitas mengayam biasa dimulai pukul 09.00
- 17.00 WIB, dengan waktu istirahat dan libur ditentukan sendiri karena jam kerja tidak diatur oleh perusahaan. Hal ini disebabkan karena buruh wanita plasma industri tidak bertanggungjawab kepada perusahaan secara langsung, namun kepada pengepul (sensir) yang merupakan penghubung antara pihak perusahaan dengan buruh plasma. Tugas sensir adalah menyalurkan bahan baku produksi, memastikan bahan baku diolah menjadi barang setengah jadi, membawa bulu mata palsu setengah jadi ke pabrik, dan menjadi perantara bagi perusahaan dalam melakukan pembayaran produk.

Ada beberapa jenis bulu mata yang dibuat seperti 5 ply, 7 ply, dan 8 ply dengan upah yang berbeda untuk masing-masing jenis. Berdasarkan hasil wawancara yang dilakukan pada saat pra lapangan, rata-rata dalam waktu satu minggu para buruh plasma wanita ini mendapatkan penghasilan sekitar Rp 500.000,00 untuk 150 paket bulu mata, dan tentunya upah ini masih dibawah UMK Kabupaten Purbalingga.

Keberadaan plasma industri bulu mata palsu bagaikan dua sisi mata uang. Positifnya, ibu rumah tangga di Desa Grantung dapat lebih berproduktif karena memiliki mata pencaharian. Peningkatan produktifitas ini mampu memberikan pemasukan berupa penghasilan tambahan yang dapat membantu perekonomian dan meningkatkan daya beli keluarga meskipun tidak terlalu signifikan karena pendapatan yang diperoleh masih di bawah UMK. Disisi lain, plasma industri melahirkan permasalahan dalam hal keberfungsian keluarga.

Menurut masyarakat Desa Grantung yang hidup bertetangga dengan pekerja plasma industri, disebabkan kesibukan buruh wanita plasma industri dalam menganyam, membuat 
mereka kurang aktif dalam berinteraksi dengan lingkungannya. Sayangnya ketotalitasan mereka untuk memenuhi target perusahaan, tidak dibarengi dengan jaminan kesejahteraan buruh yang harusnya mereka peroleh. Selain itu, mengacu pada Profil Desa Grantung tahun 2019, orientasi bekerja sejak usia dini menjadikan mereka tidak mengenyam pendidikan tinggi. Kemudian, yang menjadi perhatian utama adalah terkait upah buruh wanita plasma industri yang masih dibawah UMK Kabupaten Purbalingga. Berdasarkan hasil wawancara yang dilakukan pada beberapa buruh plasma industri, rata-rata penghasilan yang mereka peroleh perbulannya adalah sebesar Rp500.000,- padahal besaran UMK Kabupaten Purbalingga adalah Rp1.788.500,-Penghasilan ini tergolong kecil mengingat resiko jangka panjang yang harus ditanggung oleh buruh wanita plasma industri.

Keberfungsian keluarga merujuk pada kualitas kehidupan keluarga, baik pada level sistem maupun subsistem, dan berkenaan dengan kesejahteraan, kompetensi, kekuatan, dan kelemahan keluarga (Shek dalam Sri Lestari, 2012).

Keterlibatan buruh wanita dalam sektor industri menuntut mereka untuk melaksanakan peran ganda, yakni sebagai ibu rumah tangga dan pencari nafkah yang keduanya menuntut kewajiban dan tanggung jawab untuk dilakukan secara bersamaan. Berdasarkan penelitian yang telah dilakukan oleh Rahmaharyati, Wibhawa, Nurwat (2017), seringkali buruh perempuan mengalami dilema atas dua peran tersebut, perasaan bersalah kerapkali muncul ketika dihadapkan dengan situasi yang mengharuskan keberadaannya dalam keluarga. Namun disisi lain terikat oleh jam kerja yang panjang dan tidak teratur membuat buruh perempuan sulit mengatur tugas dalam keluarga. Tak jarang diantara buruh perempuan mengalami stres, emosi serta gangguan kesehatan. Selain itu tak jarang menimbulkannya konflik dalam keluarga, mengalami perselisihan dengan anggota keluarga serta komunikasi tidak berjalan dengan baik. Akibat dari buruh perempuan tidak dapat melaksanakan peranperannya, maka tidak menutup kemungkinan akan menimbulkan permasalahan. Permasalahan tersebut meliputi menurunnya kemampuan dalam menjalankan peranannya, buruknya relasi buruh wanita dengan anggota keluarganya, terganggunya komunikasi antar anggota keluarga serta tidak mampu untuk mengatasi masalah yang timbul dalam keluarga (Rahmaharyati, Wibhawa, Nurwati: 2017). Dengan demikian, maka perlu upaya agar keseimbangan peran ganda buruh wanita ini dapat terwujud sehingga suatu keniscayaan untuk menjaga keberfungsian keluarga dapat diperoleh dan selalu berjalan optimal.

Terdapat empat atribut primer keberfungsian keluarga yang sehat, menurut Hodges dalam Dubowitz dan DePanfilis (2000:346), yaitu:

\section{Connections}

"Connection is a family access to resourcess and support-support from outside the household. All families need resourcess outside the family unit in order to function optimally. Beyond the resourcess of households include extended family members, neighbors and friends, school, work, health and mental health services, religious institutions, recreational activities and groups and other civic community."

\section{Asset}

"This element focuses on skills-skills and capabilities that enable families to function well, such as nurturing skills (parenting skills), knowledge about child development, 
and child expectations appropriate to their age and capabilities problem."

\section{Relationship}

"This elements access the relationship with members of your household, communication patterns and roles, and their effect on relationships among family members. And the nature and quality of relationship with family members is a key factor in assessing family functioning."

\section{Environment}

"Elements include the adequacy of resources-environmental resources necessary to meet the needs of daily living family members. For example, economic resources, such as sources of income, income stability, and inadequate income. Environmental resources also consist of home security, adequate living arrangements, adequate space, basic home equipment (furniture, toilets, showers, cooking tools, and bedding), household management tasks as well as reguler and adequate food."

Selain itu, menurut Adi Fahrudin (2012), ada banyak model atau teori mengenai keberfungsian keluarga namun sangat sedikit penjelasan mengenai ukuran keberfungsian keluarga. Dunst, Trivette dan Deal dalam Adi Fahrudin (2012) menyarankan beberapa indikator keberfungsian institusi keluarga yaitu:

1. Nilai keluarga yaitu nilai-nilai yang dianut dan yang diamalkan oleh semua anggota keluarga. Nilai-nilai keluarga tersebut diantaranya;

a. Percaya dan mempunyai komitmen terhadap meningkatkan kesejahteraan dan perkembangan anggota keluarga dan juga unit keluarga itu sendiri. b. Nilai, peraturan, dan sistem kepercayaan yang jelas dan menerangkan tingkah laku yang boleh dan tidak boleh diterima.

c. Hidup dengan penuh tujuan baik dalam waktu senang maupun susah.

d. Berbagi tanggungjawab.

e. Menghormati hak pribadi anggota keluarga.

f. Mempunyai ritual dan tradisi keluarga

g. Mempercayai kepentingan untuk menjadi aktif dan mempelajari persoalan baru.

h. Mempercayai bahwa segala sesuatu masalah bisa diselesaikan jika anggota keluarga bekerjasama.

i. Mempertimbangkan tentang integrasi dan kesetiaan keluarga.

2. Keterampilan Keluarga menilik kemampuan keluarga dan anggotanya bertahan dalam berbagai situasi yang dihadapinya. Kemampuan tersebut diantaranya;

a. Mempunyai strategi daya tindak (coping strategy) yang berbagai bagi menangani peristiwa kehidupan yang normal dan bukan normal.

b. Mengamalkan ciri fleksibelitas dan adaptif dalam mengidentifikasi dan mendapatkan sumber bagi memenuhi kebutuhan.

c. Ilmu dan keterampilan yang digunakan untuk mengidentifikasi kebutuhan dan menetapkan hasil.

d. Kemampuan untuk mengekalkan ciri positif dalam semua aspek kehidupan termasuk melihat krisis dan tantangan sebagai peluang untuk berkembang.

e. Kemampuan untuk menggerakkan anggota keluarga untuk memperoleh sumber-sumber yang diperlukan. 
f. Kemampuan mewujudkan dan mengekalkan hubungan harmonis di dalam dan di luar sistem keluarga.

g. Kemampuan merencanakan dan menyusun tujuan keluarga.

3. Pola interaksi merujuk pada kemampuan keluarga dan anggotanya membangun dan mengembangkan pola-pola interaksi sosial baik di dalam keluarga maupun di luar keluarga. Pola interaksi ini terdiri dari;

a. Anggota keluarga saling bersetuju mengenai nilai dan kepentingan menggunakan waktu dan tenaga keluarga dalam menetapkan tujuan, mengidentifikasi kebutuhan, dan melaksanakan fungsi.

b. Menghargai sumbangan dan pencapaian besar dan kecil anggota keluarga dan mendorong anggota keluarga untuk terus berusaha memperbaikinya.

c. Bersatu dalam menjalankan aktivitas keluarga.

d. Berkomunikasi secara efektif dan sentiasa menggalakkan sumbangan ide dan kritik positif dari anggota.

e. Mengamalkan praktek mendengarkan secara efektif terhadap masalah, kehendak, kekecewaan, aspirasi, ketakutan dan harapan anggota keluarga dengan penuh dukungan.

f. Meluahkan pengukuhan dan dukungan terhadap dan sesama anggota keluarga.

Penelitian tentang keluarga yang sehat merujuk kepada keberfungsian primer keluarga tersebut. Penelitian mengenai konsep dan instrumentasi keberfungsian keluarga telah memperoleh perhatian luas sejak kebelakangan ini, dan penjelasan konsep serta indikator keberfungsian tersebut kini oleh Walker dalam Adi Fahrudin (2012) telah dibagi ke dalam enam area keberfungsian yaitu;
1. Peranan Keluarga (Roles)

Peranan adalah pola perilaku individu yang berulang dan dijalankan sesuai dengan fungsi dalam kehidupan keluarga hari ke hari. Peranan menggambarkan stuktur keluarga dan memelihara proses interaksi dalam keluarga.

a. Wujud diferensiasi yang jelas antara peranan orang tua, anak, dan pasangan.

b. Peranan mungkin dibagi, kebalikan atau perubahan, tergantung pada situasi.

c. Peranan baru dapat dicoba dan peranan lama dimodifikasi.

d. Peranan ini juga selaras merentasi situasi dan anggota-anggota keluarga.

e. Orang tua berbagi dalam perawatan dan pengasuhan anak.

2. Ekspresi emosi keluarga (emotionalexpression)

Ekspresi emosi merujuk kepada ide bahwa setiap keluarga mempunyai suasana emosi yang akan menentukan derajat emosi yang ekspresif, sensitivitas, dan kebertanggungjawaban anggota keluarga dengan anggota yang lainnya. Keluarga juga menciptakan norma timbal balik yang mengatur pola refleksi dan ekspresi emosi.

a. Keseluruhan suasana emosi keluarga adalah positif.

b. Anggota keluarga sensitif dengan perasaan anggota keluarga yang lain.

c. Aturan untuk mengekspresikan emosi adalah jelas, dan ekspresi emosi cenderung bersifat spontan.

d. Ekspresi emosi yang negatif dibenarkan sepanjang sensitif terhadap orang lain.

e. Rasa ekspresi adalah tinggi, dengan ketawa, humor dan hangat.

f. Keluarga toleransi dan mendorong ekspresi perasaan anggotanya 
3. Saling Ketergantungan/Individuasi Keluarga (interdependence/individuation)

Saling ketergantungan/individuasi merujuk kepada besarnya otonomi atau individuasi yang diberikan kepada invididu oleh keluarga.

a. Setiap individu mempunyai aktivitas sosial dan rekreasi sendiri.

b. Anggota keluarga mendiskusikan masalah individu dan memahami serta memberi dukungan kepada yang lain.

c. Perbedaan sistem nilai ditoleransi oleh keluarga; bagaimanapun nilai utama berkaitan dengan seks, uang, agama, etika kerja, kesetiaan keluarga dipegang bersama.

d. Kerjasama bukan kompetisi adalah nilai keluarga.

e. Hubungan interpersonal dengan anggota bukan keluarga dihargai sepanjang rutinitas keluarga tidak terganggu.

f. Anggota keluarga mengambilalih tanggungjawab bagi perasaan dan tingkah laku

g. Perbedaan opini dihargai, dan kesepakatan bersama selalunya hasil dari diskusi

4. Distribusi kekuasaan keluarga (power distribution)

Kekuasaan dapat diartikan sebagai derajat pengaruh atau kontrol anggota keluarga terhadap anggota keluarga yang lain. Penggunaan kekuasaan dan distibusi dikalangan anggota keluarga sangat penting untuk memahami dan perubahan pola-pola interaksi yang disfungsional.

a. Semua orang dapat memberi input dalam keputusan keluarga;

b. Anggota keluarga melihat dan mengambil kepemimpinan dalam aspek kehidupan keluarga yang berbeda dan anggota keluarga yang lain mengikuti kepemimpinan itu; c. Kekuasan dalam keluarga adalah terpusat pada kedua orang tua;

d. Peraturan keluarga dilaksanakan melalui persuasi daripada intimidasi. Kekerasan tidak ditoleransi;

e. Konflik cenderung terbuka dan penyelesaian perlu diambil secepatnya.

5. Komunikasi Keluarga (communication)

Komunikasi berkaitan dengan

penyampaian dan penerimaan informasi verbal dan non verbal antara anggota-anggota keluarga. Ini termasuk keterampilanketerampilan dalam pola-pola pertukaran informasi dalam sistem keluarga.

a. Informasi didapat dan dibagi antara anggota keluarga;

b. Pesan verbal dan non verbal adalah kongruen dan intensitas setiap pesan jelas dan terbuka;

c. Konflik diselesaikan melalui diskusi;

d. Kebanyakan komunikasi keluarga dengan nada yang positif;

e. Semua anggota keluarga mempunyai kemampuan menggunakan pemecahan masalah yang dapat menyelesaikan konflik secara efisien

6. Sub sistem Keluarga (subsystem)

Komponen yang juga penting adalah sub sistem atau sub kelompok dalam keluarga dan bagaimana mereka memelihara sistem keluarga. Jenis-jenis sub sistem termasuk orang tua, pasangan (suami atau isteri), dan kelompok adik beradik, dan aliansi antara dan di kalangan anggota kelompok.

a. Kejelasan sepadan antara sub sistem orang tua, pasangan dan adik beradik;

b. Setiap sub sistem melaksanakan fungsinya dengan tepat;

c. Ikatan emosional yang kuat antara sub sistem - sub sistem dan antara individuindividu dalam sub sistem tersebut; 
d. Sub sistem orang tua memimpin keluarga dan kebanyakannya memegang kuasa;

e. Individu-individu dalam sub sistem berpartisipasi dalam aktivitas bersama;

f. Koalisi antara sub sistem terjalin tetapi jangka pendek sifatnya.

\section{METODE}

Berdasarkan latar belakang diatas, maka variabel yang digunakan dalam penelitian ini adalah keberfungsian keluarga buruh wanita plasma industri bulu mata palsu di Desa Grantung Kecamatan Karangmoncol. Dalam variabel tersebut akan digunakan empat instrumen sesuai dengan pendapat Hodges dalam Dubowitz dan DePanfilis (2000), yaitu connections, asset, relationship, dan environment.

Metode yang digunakan dalam penelitian ini adalah metode deskriptif dengan pendekatan kuantitatif. Menurut Soehartono (2004) mengatakan penelitian deskriptif adalah penelitian yang bertujuan "memberikan gambaran tentang suatu masyarakat atau suatu kelompok tertentu atau gambaran tentang suatu gejala atau hubungan antara dua gejala atau lebih". Selanjutnya, menurut Sugiyono (2017), penelitian kuantitatif dapat diartikan sebagai metode penelitian berlandaskan filsafat positivisme yang digunakan untuk meneliti populasi atau sampel tertentu, pengumpulan data menggunakan instrumen penelitian, analisis data bersifat kuantitatif/statistik, dengan tujuan untuk menguji hipotesis yang telah ditetapkan.

Populasi dalam penelitian ini adalah buruh wanita plasma industri bulu mata palsu yang berada di Desa Grantung Kecamatan Karangmoncol Kabupaten Purbalingga yang berjumlah 25 orang. Teknik penarikan sampel untuk menentukan responden yang peneliti gunakan adalah probability sampling dengan melibatkan semua anggota populasi sebagai sampel (sensus). Hal ini dilakukan karena jumlah populasi buruh wanita plasma industri yang ada di Desa Grantung Kecamatan Karangmoncol relatif kecil yaitu kurang dari 30 orang.

Uji validitas yang akan digunakan dalam penelitian ini adalah face validity (validitas muka). Validitas muka adalah teknik pengukuran alat ukur dengan cara mengkonsultasikan kepada ahlinya, dalam hal ini yang diminta menjadi ahli adalah Dr. Theresia Martina Marwanti, M.Si dan Drs. Wawan Heryana, M.Pd selaku dosen di Poltekesos Bandung.

Alat ukur yang digunakan dalam penelitian ini menggunakan rating scale dan memiliki tingkat reliabilitas tinggi yaitu sebesar 0,708 dari 40 item pertanyaan.

Pengumpulan data menggunakan kuisoner yaitu instrumen berisikan 40 pertanyaan, dengan empat alternatif jawaban yang diberikan kepada responden untuk mendapatkan informasi mengenai buruh wanita plasma industri bulu mata palsu di Desa Grantung Kecamatan Karangmoncol Kabupaten Purbalingga.

Penelitian ini juga menggunakan studi dokumentasi yaitu dengan melakukan kajian dokumen untuk memperoleh data yang dapat dipelajari seperti bahan-bahan tertulis dalam bentuk laporan, catatan, arsip yang berhubungan dengan permasalahan penelitian buruh wanita plasma industri bulu mata palsu di Kabupaten Purbalingga. 


\section{HASIL PENELITIAN}

\section{Keberfungsian Keluarga pada Aspek} Koneksi (Connection)

Koneksi adalah akses keluarga terhadap berbagai sumber daya dan dukungan yang berasal dari luar rumah tangga agar tetap dapat berfungsi secara optimal. Berikut adalah hasil penelitian tentang aspek koneksi yang diperoleh dari 25 responden:

Grafik 1. Kategori Jawaban Aspek Koneksi

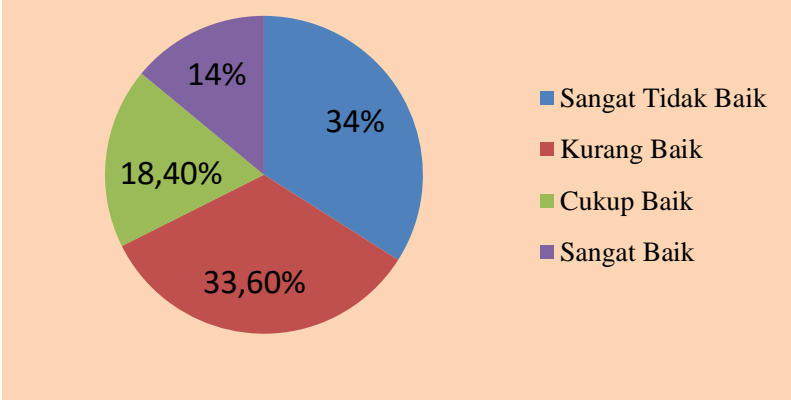

Gambar 1. Frekuensi Keberfungsian Keluarga pada Aspek Koneksi Responden

Berdasarkan gambar 1, aspek koneksi dalam keberfungsian keluarga buruh wanita plasma industri bulu mata palsu di Desa Grantung berada pada kategori sangat tidak baik dengan presentase sebesar 34\%. Dengan rincian yang dapat dilihat pada grafik 1 .

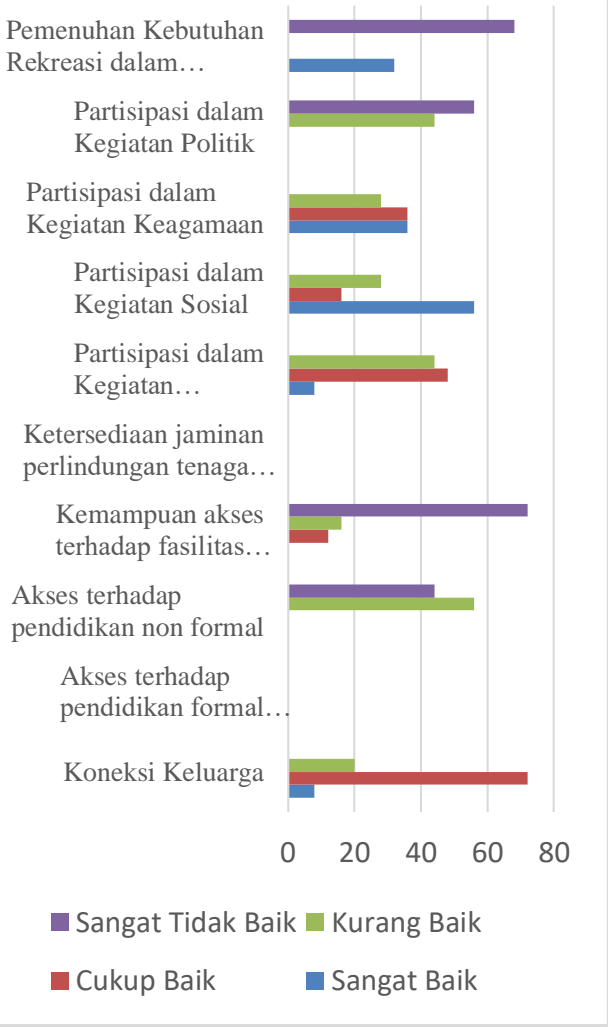

Pada grafik 1, menunjukkan bahwa sebagian besar responden sangat tidak baik dalam menjalankan aspek koneksinya. Beberapa aspek seperti akses terhadap fasilitas pendidikan, kesehatan, jaminan perlindungan tenaga kerja, dan rekreasi nyatanya belum terpenuhi secara memadai. Hal ini diakibatkan keterbatasan penghasilan yang diperoleh dan belum adanya regulasi yang mengatur keberadaan buruh plasma industri. Tetapi selain sub-aspek tersebut, sub-aspek lain yang menyangkut partisipasi aktif responden di kegiatan kemasyarakatan, religi, sosial, dan politik termasuk koneksi dengan extended family, lingkungan masyarakat, dan lingkungan kerja telah terlaksana dengan baik.

\section{Keberfungsian Keluarga pada Aspek Aset (Asset)}

Dalam kehidupan berkeluarga, kemampuan untuk memenuhi kebutuhan harus sebanding dengan kemampuan melaksanakan peranan sesuai dengan statusnya di keluarga. Disini baik suami maupun istri wajib berkolaborasi untuk menciptakan kondusifitas keluarga sehingga mencapai predikat yang harmonis. Aspek aset di dalam keluarga memfokuskan pada keterampilan dan semua kemampuan yang memungkinkan keluarga dapat berfungsi dengan sehat. Berikut adalah hasil penelitian tentang aspek aset yang diperoleh dari 25 responden:

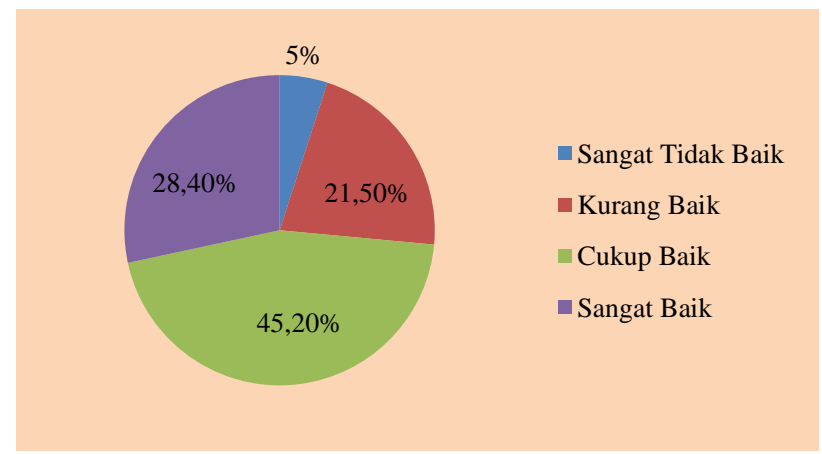

Gambar 2. Frekuensi Keberfungsian Keluarga pada Aspek Aset Responden 
Berdasarkan gambar 2, aspek aset dalam keberfungsian keluarga buruh wanita plasma industri bulu mata palsu di Desa Grantung berada pada kategori cukup baik dengan presentase sebesar $45,20 \%$. Dengan rincian yang dapat dilihat pada grafik 2 .

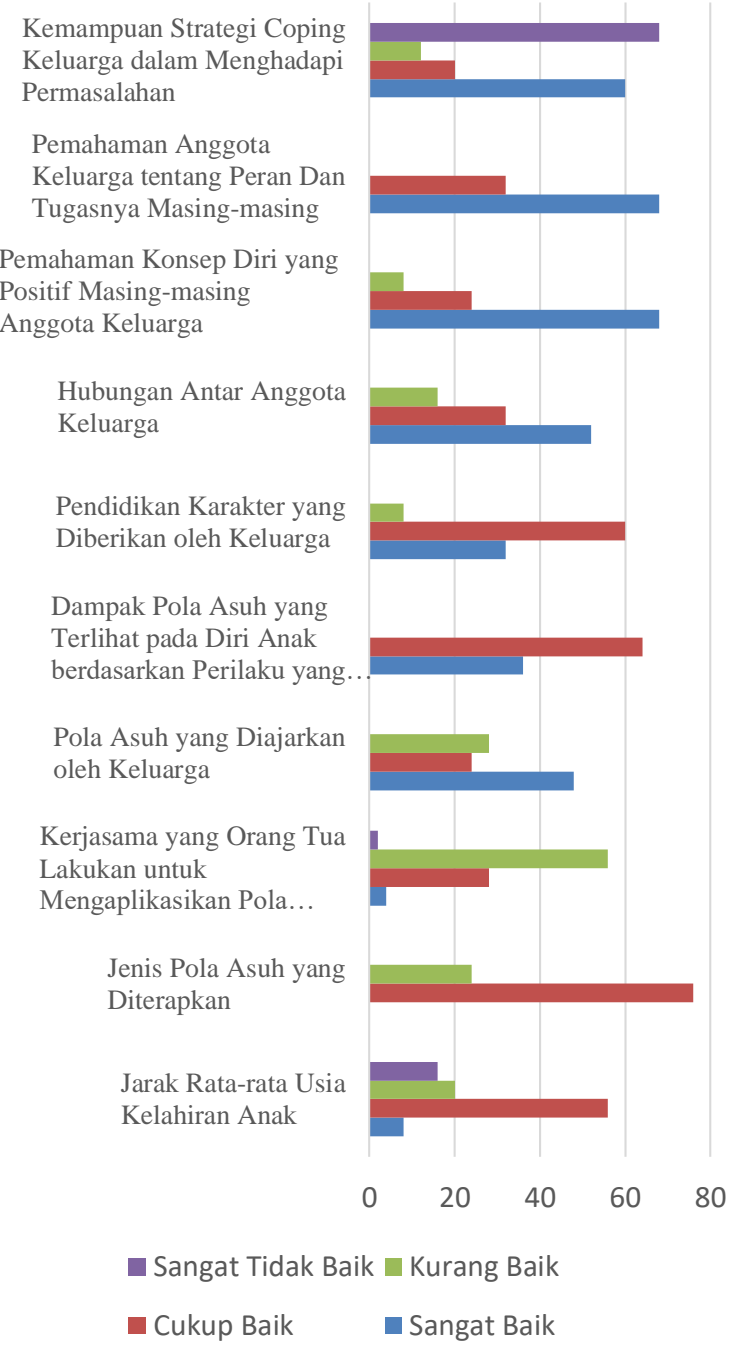

Grafik 2. Kategori Jawaban Aspek Aset

Pada grafik 2, menunjukkan bahwa sebagian besar responden cukup baik dalam menjalankan aspek asetnya. Pelaksanaan aspek aset ini juga tidak sama untuk masing-masing keluarga responden dan meskipun antar pertanyaan itu berkaitan tetapi jawaban responden tidak dapat diprediksi. Hal ini disebabkan karena keterbatasan pengetahuan responden terhadap berbagai teori yang berkaitan dengan pola asuh dan kemampuan pemecahan masalah. Sehingga dalam penerapannya mereka hanya berpatokan pada pengajaran nilai-nilai yang baik dan benar di masyarakat serta mengajarkan agar anak meminimalisir perilaku negatif yang berimbas pada penolakan lingkungan. Hasil yang terlihat dari penerapan aspek ini adalah lahirnya generasi muda di Desa Grantung khususnya Kadus IV yang beradab dan memiliki etika yang baik di lingkungannya, namun sayangnya mereka masih menampakkan rasa kurang percaya diri apabila harus keluar dari lingkungan tempat tinggalnya.

\section{Keberfungsian Keluarga pada Aspek Relasi (Relationship)}

Relasi merupakan hubungan timbal balik antara dua orang individu atau lebih dan saling mempengaruhi. Relasi dapat berlangsung secara baik maupun buruk tergantung pada intensitas dan kedalaman komunikasi yang dijalin oleh masing-masing individu ketika mengadakan kontak/hubungan dengan orang lain. Pada dasarnya faktor kunci dalam menilai keberfungsian keluarga adalah hakekat dan

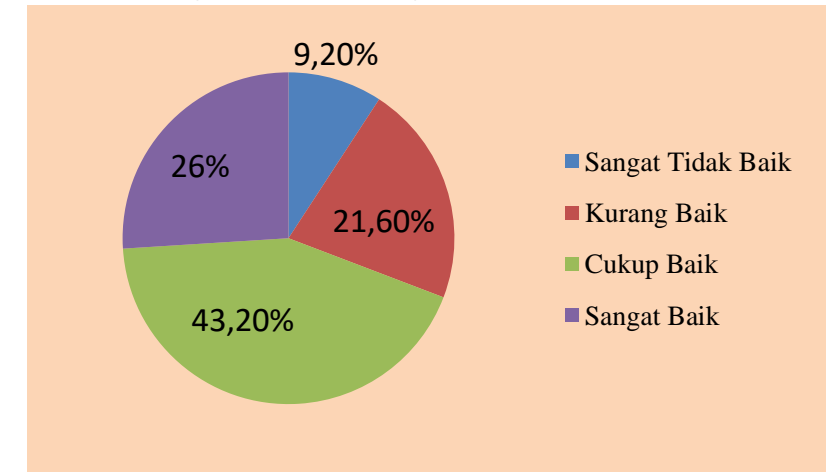

Gambar 3. Frekuensi Keberfungsian Keluarga pada Aspek Relasi Responden

Berdasarkan gambar 3, aspek relasi dalam keberfungsian keluarga buruh wanita plasma industri bulu mata palsu di Desa Grantung berada pada kategori cukup baik 
dengan presentase sebesar 43,20\%. Dengan rincian yang dapat dilihat pada grafik 3 .

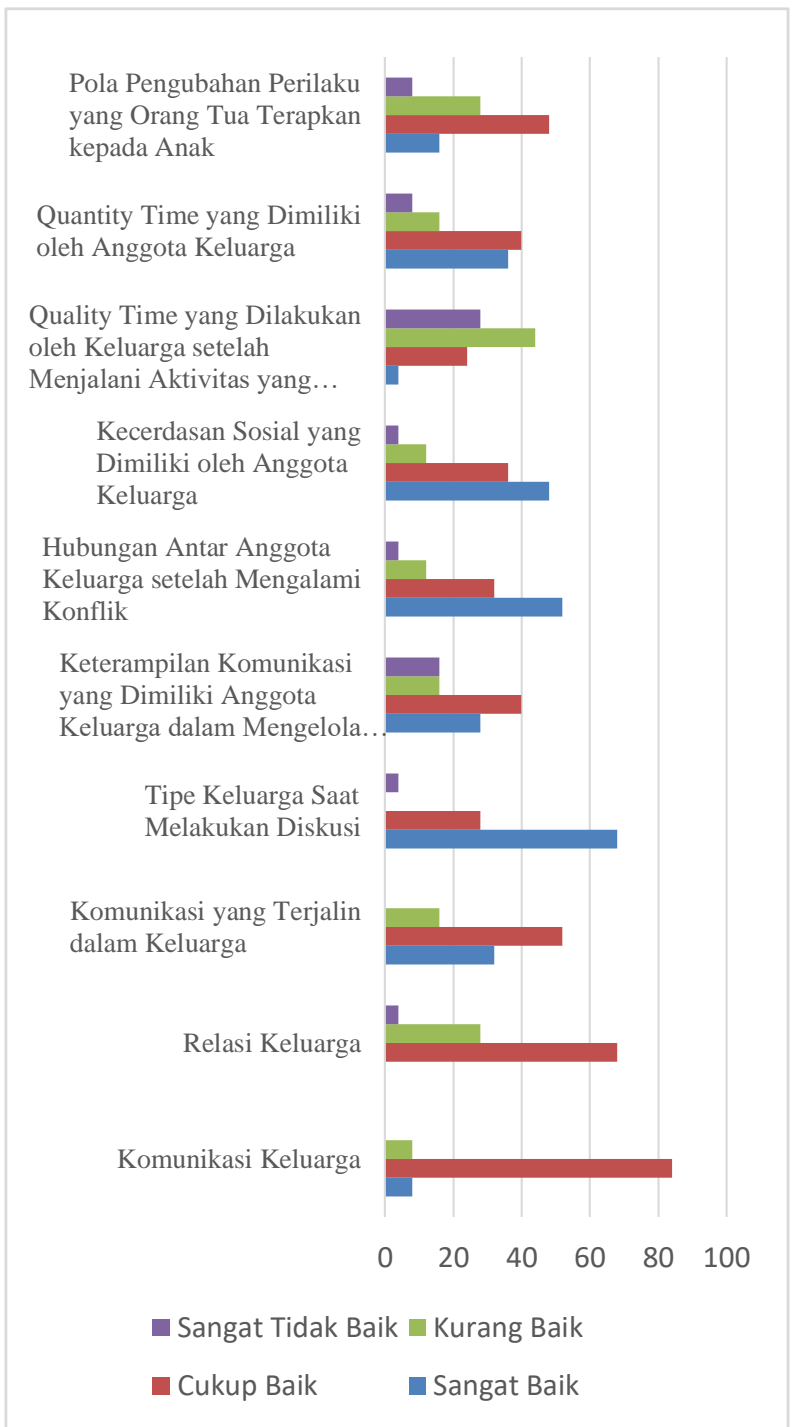

\section{Grafik 3. Kategori Jawaban Aspek Relasi}

Pada grafik 3, menunjukkan bahwa sebagian besar responden cukup baik dalam menjalankan aspek relasinya. Aspek relasi berada di lingkup keluarga inti responden, yang tentunya antar keluarga akan memiliki gayanya masing-masing dalam menerapkan aspek ini. Keberadaan aspek relasi juga memiliki hambatan yang sama dengan penerapan aspek aset, dimana responden belum memiliki ilmu yang mumpuni dalam menerapkan relasi yang baik dan berkualitas sesuai dengan teori yang berlaku. Dalam pelakasanaannya, responden dapat menilai bahwa anggota keluarganya dapat menerapkan aspek ini secara baik apabila mereka memiliki hubungan yang dekat, sopan santun terhadap orang yang lebih tua, menyayangi orang yang lebih muda, saling tolong menolong, dan diterima oleh masyarakat (tidak ada aduan bahwa anggota keluarga responden membuat ulah).

\section{Keberfungsian Keluarga pada Aspek Lingkungan (Environment)}

Keberlangsungan suatu keluarga selain dipengaruhi oleh fungsi afektif yang selalu dipupuk dan dijaga, juga memperhatikan fungsi ekonomi guna mempertahankan kelangsungan hidup anggota keluarga. Hal ini juga termasuk pada penyediaan barang-barang penunjang kebutuhan sehari-hari. Aspek ini mencakup kecukupan berbagai sumber daya lingkungan yang diperlukan untuk memenuhi kebutuhan hidup sehari-hari anggota keluarga. Misalnya sumber daya ekonomi (sumber penghasilan, stabilitas penghasilan, dan memadainya penghasilan), ketersediaan sumber daya lingkungan (keamanan rumah, pengaturan hidup yang memadai, perlengkapan dasar rumah), pengelolaan tugas-tugas rumah tangga serta makanan yang teratur dan memadai. Berikut adalah hasil penelitian tentang aspek lingkungan yang diperoleh dari 25 responden:

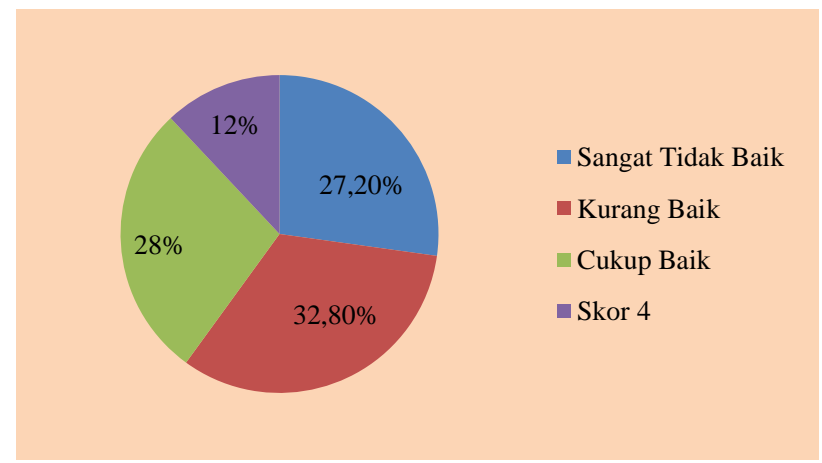

Gambar 4. Frekuensi Keberfungsian Keluarga pada Aspek Lingkungan Responden 
Berdasarkan gambar 4, aspek lingkungan dalam keberfungsian keluarga buruh wanita plasma industri bulu mata palsu di Desa Grantung berada pada kategori kurang baik dengan presentase sebesar 32,80\%. Dengan rincian yang dapat dilihat pada grafik 4 .

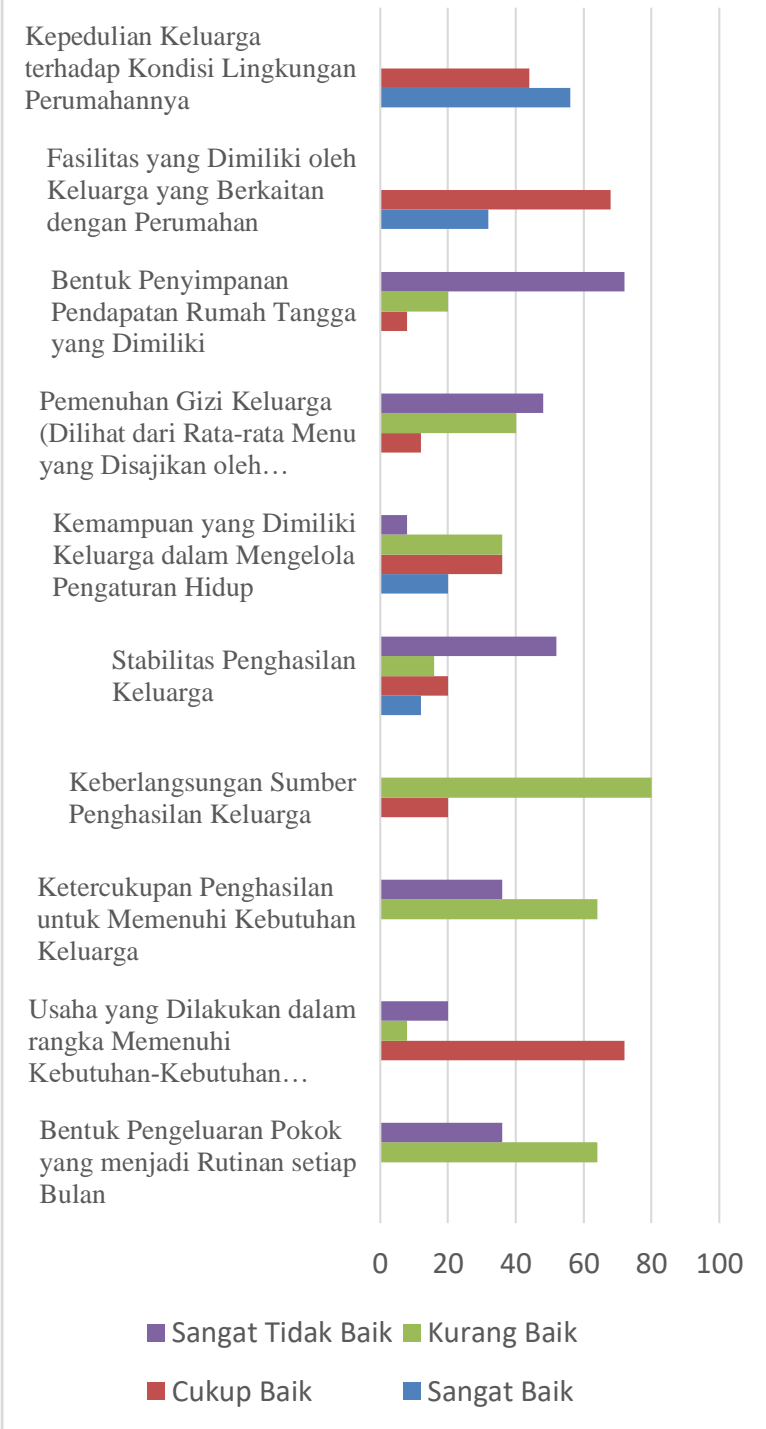

\section{Grafik 4. Kategori Jawaban Aspek Lingkungan}

Pada grafik 4, menunjukkan bahwa sebagian besar responden kurang baik dalam menjalankan aspek lingkungannya. Aspek ini masuk kategori kurang baik karena keterbatasan penghasilan yang mereka peroleh berpengaruh pada terbatasnya pemenuhan kebutuhan sehari-hari. Meskipun responden bukan pencari nafkah utama dalam keluarga, namun kepala keluarga responden pun memiliki penghasilan yang tidak menentu. Hal ini diakibatkan karena kepala keluarga mereka berprofesi sebagai petani ataupun buruh harian lepas, sehingga penghasilan yang diperoleh hanya cukup untuk memenuhi kebutuhan sehari-hari. Oleh karena itu, tidak heran apabila responden sangat terbantu dengan bantuan yang diberikan oleh pemerintah sebagai upaya menunjang kehidupan keluarga mereka terutama dalam pemenuhan kebutuhan pendidikan dan kesehatan.

\section{PEMBAHASAN}

Tabel 1. Skor Aspek Keberfungsian Keluarga

\begin{tabular}{|c|l|c|}
\hline No & \multicolumn{1}{|c|}{ Aspek } & Skor \\
\hline 1 & $\begin{array}{l}\text { Kemampuan responden dalam } \\
\text { menghubungkan (connections) } \\
\text { sumber-sumber daya dan dukungan- } \\
\text { dukungan dari luar rumah tangga }\end{array}$ & 531 \\
\hline 2 & $\begin{array}{l}\text { Kemampuan responden dalam } \\
\text { memfokuskan (assets) keterampilan } \\
\text { dan kemampuan yang dimiliki } \\
\text { memungkinkan keluarga dapat } \\
\text { berfungsi secara sehat }\end{array}$ & 733 \\
\hline 3 & $\begin{array}{l}\text { Kemampuan responden dalam } \\
\text { menjalin hubungan (relationships) } \\
\text { dengan anggota keluarga lain }\end{array}$ & 715 \\
\hline 4 & $\begin{array}{l}\text { Kemampuan responden dalam } \\
\text { mendapatkan sumber daya-sumber } \\
\text { daya lingkungan yang memadai } \\
\text { (environment) untuk memenuhi } \\
\text { kebutuhan hidup sehari-hari anggota } \\
\text { keluarga }\end{array}$ & \\
\hline
\end{tabular}

\section{Kemampuan responden dalam menghubungkan (connections) sumber- sumber daya dan dukungan-dukungan dari luar rumah tangga}

Salah satu aspek yang dikaji dalam penelitian ini ialah aspek koneksi. Diketahui dari hasil penelitian terhadap 25 responden yang ada di Desa Grantung khususnya Kadus 
IV, mengatakan bahwa aspek koneksi masuk dalam kategori kurang baik jika dilihat dari garis kontinum dengan jumlah skor 531. Wujud dari aspek koneksi tersebut ditunjukkan dalam hubungan buruh wanita plasma industri yang terjalin baik dengan extended family, lingkungan masyarakat, dan lingkungan kerja. Meskipun demikian hubungan baik dengan lingkungan kerja ini hanya terbatas pada kolega (rekan kerja), karena hubungan baik dengan perusahaan inti dan serikat pekerja ini baru bisa dilakukan oleh sensir bulu mata palsu. Selain itu, berhubungan dengan kemampuan untuk mengakses pendidikan formal dan informal, fasilitas kesehatan, dan jaminan kerja yang diberikan oleh perusahaan. Sub-aspek ini masih tergolong rendah karena ketidakmampuan responden untuk mengakses pendidikan wajib 9 tahun ini, berimbas pada terbatasnya peluang kerja, sehingga tanpa adanya pilihan lain akhirnya responden memilih untuk menjadi buruh plasma industri yang tidak mensyaratkan apapun apabila ingin bergabung. Sayangnya, regulasi yang belum terbentuk mengenai jenis hubungan kerja plasma industri ini membuat mereka tidak menerima kesejahteraan buruh seperti yang diperoleh oleh buruh yang bekerja di perusahaan inti/pusat. Hal ini tentu berimbas pada ketidakmampuan buruh dalam mengakses berbagai fasilitas kesehatan yang tersedia karena penghasilan yang diperoleh hanya cukup untuk memenuhi kebutuhan pangan saja.

Aspek koneksi pun berkaitan dengan berbagai aktivitas ataupun kegiatan yang diikuti oleh buruh wanita di lingkungannya baik kegiatan kemasyarakatan, kegiatan sosial, kegiatan keagamaan, dan kegiatan politik. Disini responden menunjukkan antusiasme yang besar untuk mengikuti kegiatan-kegiatan tersebut. Selain itu, aspek ini juga terwujud dari ketercukupan kebutuhan akan rekreasi, beberapa diantaranya melakukan kegiatan rekreasi di setiap libur akhir semester anakanaknya dengan mengikuti karya wisata yang diadakan oleh sekolah. Namun pada kenyataannya, sebagian besar responden tidak pernah mencukupi kebutuhan rekreasinya karena keterbatasan biaya yang dimiliki. Sehingga responden lebih memilih untuk berekreasi secara sederhana dengan mandi di sungai maupun pergi ke sawah/kebun.

Pada penelitian ini aspek koneksi menjadi aspek terendah dalam perolehan prosentase dan masuk dalam kategori kurang baik jika dilihat dari pengukuran garis kontinum. Hodges dalam Dubowitz dan DePanfilis (2000) mengatakan bahwa aspek koneksi ini berkaitan dengan akses keluarga terhadap berbagai sumber daya dan dukungan yang berasal dari luar rumah tangga agar tetap dapat berfungsi secara optimal. Sistem sumber tersebut meliputi anggota extended family, tetangga, kawan-kawan, dan institusi (pendidikan, kesehatan, religius) maupun organisasi pelayanan sosial dengan berbagai kegiatan yang diselenggarakan serta dapat dimanfaatkan seluas-luasnya oleh keluarga. Ternyata hasil temuan dilapangan, sistem sumber tersebut tidak seluruhnya terlaksana dengan baik. Rendahnya tingkat pendidikan dan belum adanya regulasi yang mengatur secara jelas keberadaan buruh plasma industri ini menjadi permasalahan yang mendasar. Untungnya, faktor-faktor penghambat tersebut tidak berpengaruh juga terhadap kehidupan buruh wanita plasma industri bulu mata palsu di lingkungan tempat tinggalnya. Terlihat bahwa responden masih memiliki koneksi yang baik dengan lingkungan di luar keluarga intinya, mampu secara aktif berkontribusi di berbagai kegiatan yang dilaksanakan di 
lingkungannya, dan hidup dengan bahagia secara sederhana.

Selain itu, menurut Dunst, Trivette dan Deal dalam Adi Fahrudin (2012) disebutkan bahwa salah satu indikator dari keberfungsian keluarga adalah adanya pola interaksi sosial baik di dalam keluarga maupun di luar keluarga. Anggota keluarga harus saling mengukuhkan dan memberikan dukungan satu sama lain dalam menjalankan aktivitas kesehariannya. Disini sudah terlihat bahwa ditengah kesibukan responden, keluarganya masih memberikan dukungan secara penuh sehingga responden dapat tetap berkontribusi baik di kegiatan sosial, keagamaan, maupun politik di dalam masyarakat.

\section{Kemampuan responden dalam memfokuskan (assets) keterampilan dan kemampuan yang dimiliki memungkinkan keluarga dapat berfungsi secara sehat}

Aspek berikutnya adalah aspek aset (assets). Diketahui dari hasil penelitian terhadap 25 responden yang ada di Desa Grantung khususnya Kadus IV, mengatakan bahwa aspek aset masuk dalam kategori cukup baik jika dilihat dari garis kontinum dengan jumlah skor 733. Wujud dari aspek aset tersebut ditunjukkan dalam pola asuh yang diterapkan di dalam keluarga dan dampak yang terlihat akibat pola asuh yang diterapkan tersebut, termasuk pendidikan karakter yang diajarkan, hubungan antar anggota keluarga inti, serta kemampuan responden dalam menyelesaikan masalah (problem solving).

Secara konseptual aspek aset ini termasuk kedalam bagian dari atribut keberfungsian keluarga. Sebagaimana yang dikemukakan oleh Hodges dalam Dubowitz dan DePanfilis (2000) mengatakan bahwa aspek aset ini memfokuskan pada keterampilan dan semua kemampuan yang memungkinkan keluarga dapat berfungsi dengan sehat yang erat kaitannya dengan keterampilan pengasuhan (parenting skill), pengetahuan tentang perkembangan anak, harapan-harapan anak yang sesuai dengan usianya, kemampuan dalam memecahkan permasalahan. Pandangan konseptual tersebut nyatanya telah tergambarkan secara jelas di keseharian responden dalam menerapkan pola asuh terhadap anak-anaknya dan kemampuan mereka dalam memecahkan permasalahan, meskipun pemahaman akan hal-hal tersebut tidak secara teoritis (seperti pendapat ahli) melainkan berdasarkan pendapat pribadi. Kemudian cara responden meyakini bahwa hal-hal tersebut telah sesuai adalah apabila sikap dan perilaku anggota keluarganya dapat diterima oleh sistem nilai dan norma yang berlaku secara umum di masyarakat.

Walker dalam Adi Fahrudin (2012), menyebutkan bahwa salah satu indikator keberfungsian keluarga adalah tentang peranan keluarga (roles). Peranan menggambarkan stuktur keluarga dan memelihara proses interaksi dalam keluarga. Hal ini berkaitan dengan aspek aset, dimana bahwasannya masing-masing anggota keluarga telah dapat memahami dan menjalankan perannya dengan baik. Termasuk dalam proses pengasuhan dan perawatan anak, para responden senantiasa berkolaborasi mewujudkan pola pengasuhan yang terbaik meskipun ditengah keterbatasan pengetahuan dan peran ganda yang dilakoninya.

Selanjutnya, dalam jurnal yang ditulis oleh Rahmaharyati, Wibhawa, Nurwati (2017), buruh wanita yang menjalankan peran ganda mengalami kesulitan dalam mengatasi masalah yang timbul dalam keluarga karena rendahnya manajemen emosi dan pengelolaan 
stress yang kurang baik. Pada kasus ini, nyatanya hambatan-hambatan terkait peran ganda tersebut dapat dilalui dengan baik terlihat dari skor aset yang lebih tinggi dari skor aspek yang lain. Hal ini disebabkan karena pekerjaan plasma industri dikerjakan di rumah masing-masing sehingga buruh wanita dapat menjalankan perannya di dalam rumah tangga dengan baik, meskipun hal tersebut berpengaruh terhadap penghasilan yang diperoleh karena menuntaskan urusan rumah tangganya (termasuk pengasuhan anak) terlebih dahulu.

\section{Aspek Relasi (relationships) dalam rangka Menjalin Hubungan dengan Anggota Keluarga Lain}

Aspek lainnya yang terkandung dalam keberfungsian keluarga adalah aspek relasi. Diketahui dari hasil penelitian terhadap 25 responden yang ada di Desa Grantung khususnya Kadus IV, mengatakan bahwa aspek relasi masuk dalam kategori cukup baik jika dilihat dari garis kontinum dengan jumlah skor 715. Wujud dari aspek relasi tersebut ditunjukkan dari kemampuan menjalin komunikasi dan relasi dengan berbagai pihak baik keluarga, lingkungan masyarakat, maupun lingkungan kerja. Selain itu dilihat pula pola komunikasi di dalam keluarga baik saat melaksanakan diskusi sampai dengan komunikasi yang terjalin setelah terjadinya konflik. Kemudian tercermin pula dari kecerdasan sosial yang ditunjukkan oleh anggota keluarga dalam kesehariannya. Peneliti melihat aspek ini berjalan dengan baik juga melalui berbagai kegiatan yang dilakukan secara bersama-sama setelah keluarga sibuk dengan urusannya masing-masing (qualitity time); ketersediaan waktu anggota keluarga untuk berkomunikasi dan berinteraksi (quantity time); dan pola pengubahan perilaku dalam keluarga.

Pada dasarnya faktor kunci dalam menilai keberfungsian keluarga adalah hakekat dan kualitas hubungan dengan anggota keluarga. Hal tersebut sesuai dengan pandangan Hodges dalam Dubowitz dan DePanfilis (2000) yang mengatakan bahwa aspek relasi ini menilai hubungan-hubungan dengan anggota-anggota rumah tangga lain diluar keluarga inti, pola-pola komunikasi dan peran di dalam keluarga, serta efeknya terhadap hubungan - hubungan diantara anggota keluarga. Jadi selain memiliki koneksi yang baik dengan berbagai sumber dan dukungan di luar keluarga inti, anggota keluarga sejatinya tumbuh dan berkembang terlebih dahulu di dalam keluarga intinya. Sehingga mereka harus mengembangkan berbagai kemampuan dalam aspek relasi agar dapat hidup di lingkungan luarnya. Pada keluarga responden, pandangan konseptual tersebut telah terlihat dengan jelas dipraktekan dalam pembelajaran dan pembiasaan yang diberlakukan di dalam keluarga. Mereka berusaha melibatkan setiap anggota keluarganya untuk menentukan keputusan dengan cara diskusi, bersikap asertif untuk menyampaikan setiap perasaan yang dirasakan, meluangkan waktu ditengah kesibukan, dan selalu menumbuhkan rasa kasih sayang disetiap waktu. Meskipun hal-hal tersebut belum dapat terlaksana secara sempurna di setiap keluarga, namun mereka telah berusaha untuk menanamkan nilai dan norma yang mereka ketahui ditengah keterbatasan pengetahuan yang mereka miliki.

Walker dalam Adi Fahrudin (2012), selanjutnya juga menentukan indikator keberfungsian keluarga, yang di dalamnya juga selaras dengan konsep yang dikemukakan oleh Hodges. Indikator tersebut meliputi ekspresi 
emosi keluarga, saling ketergantungan/individuasi keluarga, distribusi kekuasaan keluarga, dan komunikasi keluarga. Indikator ini telah sesuai dengan apa yang dilakukan oleh responden, bahwasannya mereka telah mampu melakukan dan mengajarkan bagaimana bersikap asertif dalam rangka pengungkapan perasaan yang dialami. Hal ini tentunya didorong oleh keterampilan berkomunikasi yang baik antar anggota keluarga, saling menghargai perbedaan pendapat, saling mendukung, dan berdiskusi secara aktif dalam menyelesaikan persoalan keluarga.

Selanjutnya, dalam jurnal yang ditulis oleh Rahmaharyati, Wibhawa, Nurwati (2017), buruh wanita yang menjalankan peran ganda mengalami penurunan kemampuan dalam menjalankan peranannya, memiliki relasi yang buruk relasi dengan anggota keluarganya, dan terganggunya komunikasi antar anggota keluarga. Melihat kasus yang ada, nyatanya buruh wanita plasma industri ini mampu mengatasi hambatan terkait peran ganda tersebut, yang dibuktikan dengan perolehan skor relasi ini menjadi terbesar ke2 dari aspek yang lain. Hal ini disebabkan karena bekerja menjadi buruh plasma industri tidak terikat waktu dan jam kerja, sehingga mereka dapat mengatur sendiri porsi pekerjaan yang akan mereka lakukan. Disini buruh wanita plasma industri lebih mengutamakan perannya sebagai ibu rumah tangga, sehingga aspek relasi ini memperoleh skor yang cukup baik, tetapi berimbas juga pada rendahnya pendapatan yang mereka peroleh.

\section{Aspek Lingkungan (Environment) dalam rangka Mendapatkan Sumber Daya- Sumber Daya Lingkungan yang Memadai untuk Memenuhi Kebutuhan Hidup Sehari-Hari Anggota Keluarga}

Aspek yang terakhir yang terkandung dalam keberfungsian keluarga adalah aspek lingkungan (environment). Diketahui dari hasil penelitian terhadap 25 responden yang ada di Desa Grantung khususnya Kadus IV, mengatakan bahwa aspek lingkungan masuk dalam kategori kurang baik jika dilihat dari garis kontinum dengan jumlah skor 562 . Wujud dari aspek lingkungan ini dapat dilihat dari bentuk pengeluaran pokok tiap bulan; usaha dalam memenuhi kebutuhan yang mendesak; ketercukupan penghasilan; keberlangsungan sumber penghasilan; stabilitas penghasilan; kemampuan dalam mengelola pengaturan hidup; pemenuhan gizi keluarga; bentuk penyimpanan pendapatan; dan kondisi lingkungan perumahan.

Secara konseptual aspek lingkungan masuk ke dalam atribut keberfungsian keluarga yang berkaitan dengan pemenuhan kebutuhan ekonomi. Sebagaimana yang dikemukakan oleh Hodges dalam Dubowitz dan DePanfilis (2000) mengatakan bahwa keberlangsungan suatu keluarga selain dipengaruhi oleh fungsi afektif yang selalu dipupuk dan dijaga, juga memperhatikan fungsi ekonomi guna mempertahankan kelangsungan hidup anggota keluarga. Aspek ini mencakup kecukupan berbagai sumber daya lingkungan yang diperlukan untuk memenuhi kebutuhan hidup sehari-hari anggota keluarga. keamanan rumah, pengaturan hidup yang memadai, perlengkapan dasar rumah (perabotan, toilet, kamar mandi, alat memasak, dan perlengkapan tidur), pengelolaan tugas-tugas rumah tangga serta makanan yang teratur dan memadai. Aspek 
lingkungan ini memiliki skor yang kurang baik apabila dilihat dari pengukuran garis kontinum. Sebenarnya secara konseptual, aspek ini telah dipenuhi oleh keluarga responden secara baik meskipun belum memadai. Hal ini disebabkan karena keterbatasan perekonomian keluarga yang membuat mereka harus pandai dalam mengatur pengeluaran agar mencukupi berbagai kebutuhan yang ada. Untungnya dengan bantuan dari pemerintah yang mereka peroleh seperti KIP, KIS, BOS, PKH, dan BPNT dapat mengurangi beban keluarga yang harus dipenuhi.

Selanjutnya menurut Suharto (2004) tentang ciri kemiskinan, apabila dilihat dengan aspek lingkungan ini maka terdapat beberapa yang selaras. Responden nyatanya memiliki kesulitan akses terhadap kebutuhan akan pendidikan dan kesehatan, tidak adanya jaminan masa depan, kerentanan terhadap goncangan individu maupun masal, rendahnya kualitas sumber daya manusia, dan akses terhadap lapangan kerja yang terbatas sehingga tidak ada pilihan lain selain menjadi buruh plasma industri.

\section{KESIMPULAN}

Berdasarkan hasil penelitian dapat disimpulkan bahwa keberfungsian keluarga buruh wanita plasma industri bulu mata palsu di Desa Grantung masing berada pada kategori kurang baik - cukup baik. Hal tersebut bisa dinilai dari teori keberfungsian keluarga menurut Hodges dalam Dubowitz dan DePanfilis (2000), yang digunakan oleh peneliti, yaitu:

\section{Aspek Koneksi}

Aspek koneksi menghasilkan temuan penelitian yang menjelaskan bahwa tingkat pendidikan dan kemampuan akses terhadap fasilitas kesehatan masih belum terpenuhi secara optimal, karena keterbatasan penghasilan yang dimiliki. Ditambah lagi dengan jaminan kesejahteraan buruh yang tidak diperoleh buruh plasma industri karena hubungan kerja yang belum diatur secara jelas di dalam undang-undang maupun peraturan daerah. Tetapi hal ini tidak mempengaruhi partisipasi buruh wanita plasma industri bulu mata palsu Desa Grantung terhadap kegiatan-kegiatan yang ada di lingkungannya. Mereka masih berpartisipasi aktif baik dalam kegiatan sosial, keagamaan, maupun politik dan mampu hidup berdampingan dengan lingkungannya di tengah kesibukan yang dilakukan.

2. Aspek Aset

Aspek aset menghasilkan temuan penelitian yang menjelaskan bahwa pelaksanaan indikator yang ada pada aspek aset ini dilakukan berdasarkan hasil imitasi yang diperoleh dari keluarganya secara turun temurun. Bagi mereka ketika anak mampu menampilkan perilaku yang baik di dalam kesehariannya maka pola asuh yang mereka terapkan sudah benar. Sayangnya, mereka abai terhadap perkembangan ilmu pengetahuan yang seharusnya dapat digunakan sebagai dasar untuk menerapkan pola asuh dan pendidikan pertama bagi anak di dalam keluarga. Padahal hampir seluruh buruh wanita plasma industri bulu mata palsu Desa Grantung melek huruf dan memiliki gadget yang dapat digunakan sebagai media belajar secara otodidak.

3. Aspek Relasi

Aspek relasi selanjutnya menghasilkan temuan penelitian yang menjelaskan bahwa keluarga buruh wanita plasma industri bulu mata palsu memiliki kemampuan komunikasi dan relasi yang 
baik meskipun dengan dasar ilmu pengetahuan yang terbatas. Profesi sebagai buruh plasma industri memang menjadikan buruh wanita dapat bekerja dirumah dan bertemu dengan keluarganya setiap waktu, sehingga dalam aspek ini tidak ada hambatan yang berarti, kecuali kemauan antar anggota keluarga untuk berkomunikasi secara intens dan menyampaikan perasaanperasaannya secara aktif. Selain itu, keterbatasan penghasilan dan kesibukan yang dijalani tidak menjadikan buruh wanita plasma industri kehabisan akal untuk memanfaatkan quality time yang dimiliki, mereka biasa mengisinya dengan kegiatankegiatan sederhana namun berkesan dan memanfaatkan waktu dengan baik meskipun mereka sedang sibuk.

4. Aspek Lingkungan

Aspek lingkungan menghasilkan temuan penelitian yang menjelaskan bahwa penghasilan buruh wanita plasma industri bulu mata palsu dan kepala keluarganya hanya mampu untuk memenuhi kebutuhan sandang dan pangan. Sementara untuk kebutuhan kesehatan dan pendidikan, mereka mengharapkan bantuan dari pemerintah melalui KIS dan PIP. Hampir seluruh kepala keluarga buruh wanita plasma industri bulu mata palsu Desa Grantung bermatapencaharian sebagai pekerja serabutan yang tidak memiliki kepastian penghasilan dan stabilitasnya tidak bisa dijamin. Sehingga untuk pemenuhan kebutuhan sehari-hari pun, pangan misalnya, mereka hanya mampu menyediakan secara sederhana dan tidak memenuhi standar kelayakan gizi. Tetapi, ditengah keterbatasan yang dimiliki mereka masih peduli dengan kondisi lingkungan tempat tinggalnya.

\section{DAFTAR PUSTAKA}

Arsyad, L., Satriawan, E., Mulyo, J. H., \& Fitrady, A. (2011). Strategi pembangunan pedesaan berbasis lokal. Yogyakarta: UPP STIM YKPN.

Achlis. (1992). Praktek Pekerjaan Sosial I. Bandung: STKS Press.

Adi Fahrudin. (2012). Keberfungsian Keluarga: Konsep dan Indikator Pengukuran dalam Penelitian. Jurnal Fakultas Ilmu Sosial dan Ilmu Politik UMJ, 17(2), $75-81$.

Dwi Heru Sukoco. (1991). Profesi Pekerjaan Sosial dan Proses Pertolongannya. Bandung: Koperasi Mahasiswa Sekolah Tinggi Kesejahteraan Sosial.

Dobuwitz and DePanfilis. (2000). Handbook For Child Protection Practice. United State of America. Sage Publication, Inc.

Fahrudin, Adi. (2012). Pengantar Kesejahteraan Sosial. Bandung: PT. Refika Aditama.

Friedman. (2010). Family Nursing: Research, Theory, \& Practice. New Jersey: Pearson Education, Inc.

Harmoko. (2012). Asuhan Keperawatan Keluarga.Yogyakarta: Pustaka Pelajar.

Haryanto, (2014). Pengembangan Kapasitas Kelembagaan (Institutional Capacity Development) Teori dan Aplikasi. Jakarta: AP21-Press.

Moch. Nazir. (1988). Metode Penelitian. Jakarta: Ghalia Indonesia.

Rahmaharyati, Wibhawa, Nurwati. (2017). Peran Ganda Buruh Perempuan Sektor Industri dalam Keluarga. Jurnal Penelitian \& PKM, 4(2), $129-389$.

Soetarso. (1993). Praktek Pekerjaan Sosial. Bandung: Koperasi Mahasiswa Sekolah Tinggi Kesejahteraan Sosial Bandung.

Sugiyono. (2017). Metode Penelitian Kuantitatif, Kualitatif, dan R\&D. Bandung : Alfabeta.

Soehartono, Irawan. (2004). Metode Penelitian Sosial. Bandung: PT. Remaja Rosdakarya.

Sri Lestari. (2012). Psikologi Keluarga: Penanaman Nilai dan Penanganan Konflik dalam Keluarga. Jakarta: Prenada Media Group. 


\section{Hasil Penelitian Terdahulu}

Irhas Altameer Putra. (2014). Keberfungsian Keluarga di Kelurahan Caringin Kecamatan Bandung Kulon (Studi Kasus Terhadap Empat Keluarga di Kelurahan Caringin). STKS, Bandung.

Juaf Tika. (2017). Keberfungsian Keluarga Anak Putus Sekolah di Kelurahan Nambangan Kidul Kota Madiun. STKS, Bandung.

Panca Susilawati. (2011). Perlindungan Sosial terhadap Buruh Perempuan di Perkebunan Kelapa Sawit PT. Gunung Pelawan Lestari Desa Gunung Pelawan Kecamatan Belinyu Kabupaten Bangka. STKS, Bandung.

Ragil Utami. (2014). Tingkat Kesejahteraan Rumah Tangga Tenaga Kerja Perempuan Plasma Industri Bulu Mata Palsu di Desa Tegalpingen Kecamatan Pengadegan Kabupaten Purbalingga Provinsi Jawa Tengah. Universitas Negeri Yogyakarta.

\section{Sumber Lain}

Undang-undang Nomor 21 tahun 1994 tentang Penyelenggaraan Pembangunan Keluarga Sejahtera

Peraturan Menteri Sosial Nomor 8 tahun 2012 tentang Pedoman Pendataan dan Pengelolaan Data Penyandang Masalah

Kesejahteran Sosial dan Potensi dan Sumber Kesejahteraan Sosial

Keputusan Menteri Sosial Republik Indonesia Nomor 146/HUK2013 Tentang Penetapan Kriteria Dan Pendataan Fakir Miskin dan Orang Tidak Mampu

Undang-undang Nomor 13 tahun 2003 tentang Ketenagakerjaan

Undang-undang Nomor 9 tahun 1995 tentang Usaha Kecil

Peraturan Pemerintah Republik Indonesia Nomor 44 tahun 1997 tentang Kemitraan 